MARKETS IN OAXACA 
THIS PAGE INTENTIONALLY LEFT BLANK 
Special Publication Sponsored by the INSTITUTE OF LATIN AMERICAN STUDIES

The University of Texas at Austin 


\section{Markets in Oaxaca}

edited by

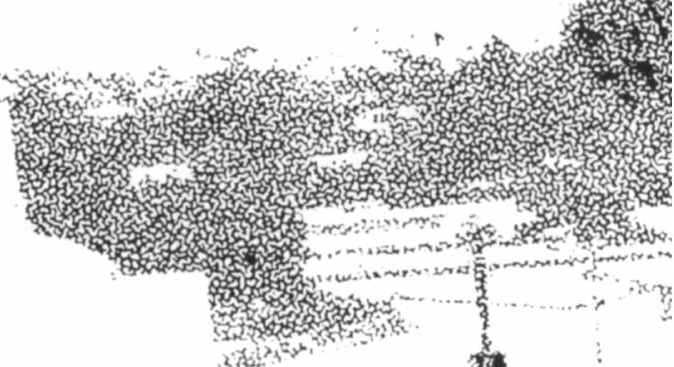

SCOTT COOK AND MARTIN DISKIN

Foreword by Sidney W. Mintz
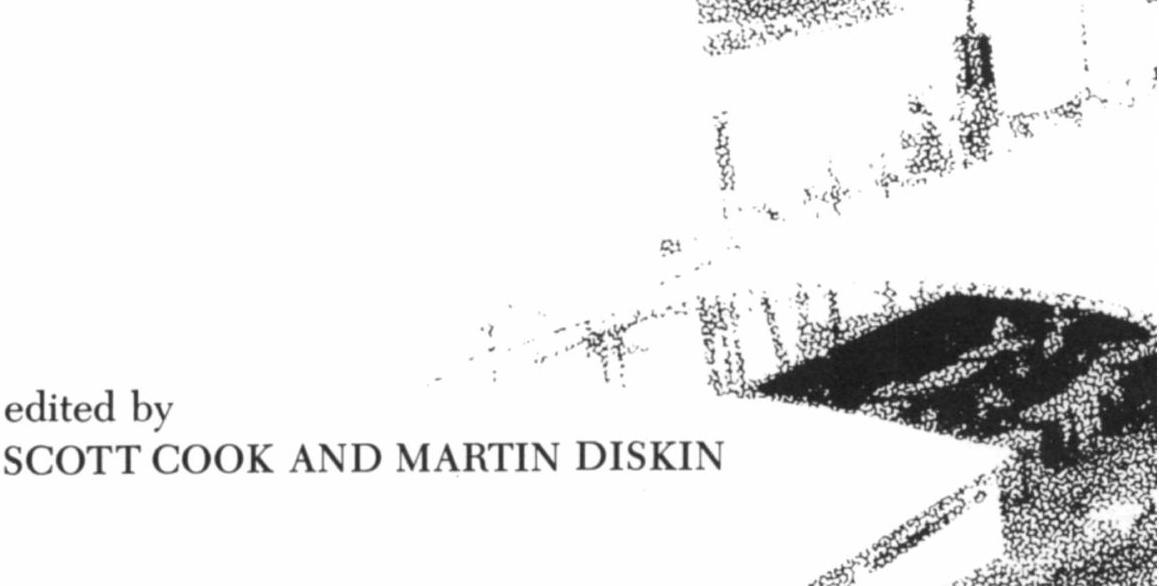

UNIVERSITY OF TEXAS PRESS

AUSTIN

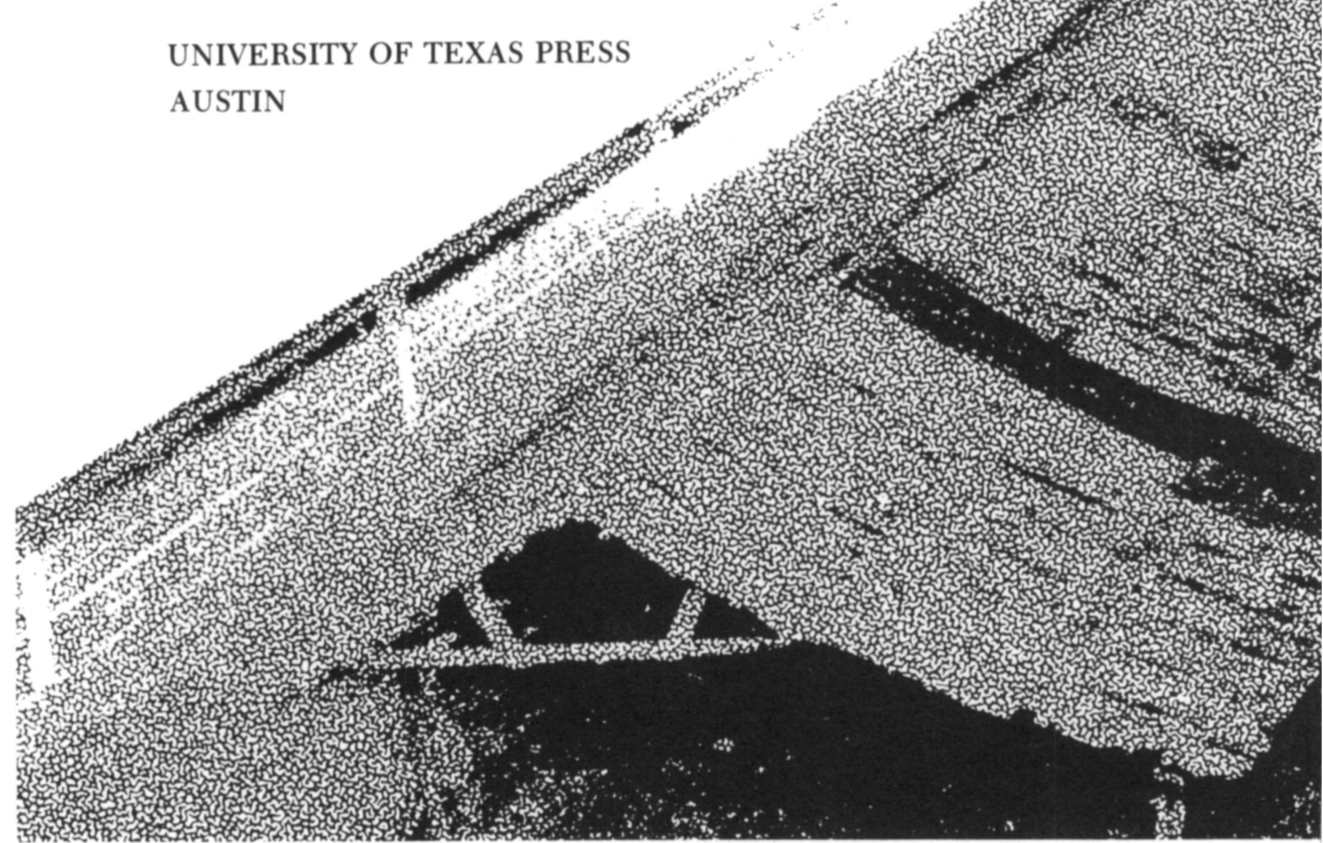


Library of Congress Cataloging in Publication Data

Main entry under title:

Markets in Oaxaca.

(Special publication sponsored by the Institute of Latin American Studies, the University of Texas at Austin)

Edited papers from a symposium held in Tucson, Apr. 30, 1971, sponsored by the Southwestern Anthropological Association.

Bibliography: $\mathrm{p}$.

Includes index.

1. Oaxaca Valley-Economic conditions. 2. MarketsMexico-Oaxaca Valley. 3. Oaxaca Valley-Social conditions. I. Cook, Scott, 1937- II. Diskin, Martin, 1934- III. Southwestern Anthropological Association. IV. Series: Texas. University at Austin. Institute of Latin American Studies. Special publication. HC137.027M37 330.9'72'7 75-8518 ISBN 0-292-75014-5

Copyright (C) 1976 by Scott Cook and Martin Diskin All rights reserved 
AL PUEBLO TRABAJADOR DE OAXACA 